Wojciech Szafrański

w.szafr@amu.edu.pl

orcid.org/0000-0001-8420-4673

Uniwersytet im. Adama Mickiewicza w Poznaniu

Wydział Prawa i Administracji

Św. Marcin 90

61-714 Poznań

\title{
Aktualne problemy i zagrożenia związane z obrotem dobrami kultury na rynku sztuki w Polsce z perspektywy prawnej ochrony zabytków
} Current Problems and Threats to Art Market in Poland from the Cultural Heritage Protection Perspective

Summary: This article presents the art market in Poland with a focus on existing problems and potential threats to its transparency. The Polish art market is young and therefore vulnerable when it comes to globally occurring trends and shifts. However, there are some trends that are typical for the Polish realm, such as the existence of non-professionals who are connected to the cultural sector because of their profession (art historians, monuments conservators, museum collaborators, journalists) and act successfully as middlemen. Diminishing risks and mitigating threats is possible with an introduction of new legal regulations and future art market self-regulation. In this regard, applicable international and European legal instruments must be taken into account.

Keywords: art market, self-regulation, codes of professional ethics

Streszczenie: W artykule zaprezentowano analizę obrotu dobrami kultury w Polsce z perspektywy istniejących problemów i zagrożeń. Krajowy rynek dzieł sztuki jako rynek młody jest narażony na występowanie zjawisk typowych dla rynków sztuki. Jednakże można 


\section{ARTYKUtY}

Wojciech Szafrański

także zaobserwować na nim występowanie mechanizmów, które są właściwe tylko temu rynkowi - zjawisko działaczy sprzedających dzieła sztuki i nieprowadzących działalności gospodarczej. Analiza wskazuje, że obniżenie ryzyka na rynku i zminimalizowanie zagrożeń może być osiągnięte poprzez zastosowanie nowej regulacji prawnej i samoregulacji uczestników rynku. W tym zakresie ważne jest dostosowanie regulacji do prawa międzynarodowego i unijnego.

Słowa kluczowe: polski rynek sztuki, samoregulacja, zagrożenia i wyzwania

\section{Zagadnienia wstępne}

Rynek sztuki w Polsce, rozwijający się od przełomu lat 1988 i 1989, wykazuje wiele cech specyficznych w stosunku do rynków zachodnich. Należy na niego spoglądać w sposób szerszy, niż to ujmują prawnicy czy ekonomiści, traktujący go jako miejsce, gdzie spotykają się oferenci i potencjalni nabywcy w celu zawarcia umowy sprzedaży dzieła sztuki, lub jako jeden z rynków branżowych, stanowiących ogół skutków wymiany między sprzedającymi a nabywającymi ${ }^{1}$. W moim przekonaniu bardziej zasadne jest formułowanie definicji rynku poprzez wskazywanie jego obszarów, a więc: sfery twórczej (m.in. artyści, twórczość artystyczna, związki artystów, wsparcie dla nich), otoczenia rynkowego (m.in. podmioty na rynku, mecenat, kolekcje, ubezpieczenia, art banking, uwarunkowania prawno-ekonomiczne, w tym regulacje dotyczące ochrony dziedzictwa), otoczenia dalszego (m.in. sytuacja społeczno-gospodarcza w kraju i na świecie, koniunktura, poziom dochodów, giełda papierów wartościowych)². Najczęściej popełnianymi błędami w ocenie rynku polskiego są:

1. Traktowanie go jako rynku dóbr luksusowych. Jest to efektem utożsamiania rynku sztuki wyłącznie z rynkiem aukcyjnym (o wyższej medialności), stanowiącym jego element i mającym wpływ na rynek antykwaryczny czy galeryjny, które są całkowicie inne, funkcjonują na innych zasadach, stąd bardzo często interesy już tylko tych trzech rodzajów podmiotów na rynku (domów aukcyjnych, antykwariatów i galerii sztuki) są przeciwstawne.

1 Por. P. Gwoździewicz, W. Kowalski, Rynek sztuki [hasło], w: K. Zeidler, Leksykon prawa ochrony zabytków. 100 podstawowych pojęć, C.H. Beck, Warszawa 2010, s. 334-335.

2 Zob. J. Białynicka-Birula, Rynek dzieł sztuki w Polsce. Aspekty prawno-ekonomiczne, Ministerstwo Kultury i Dziedzictwa Narodowego [2008], s. 2-3, http://www.kongreskultury.pl/library/File/RaportRynekSzt/ rynek_dziel_sztuki_raport_w.pelna(1).pdf [dostęp: 5.05.2019]. Raport przygotowany na Kongres Kultury Polskiej w Krakowie w 2008 r. jako jeden z Raportów o Stanie Kultury zleconych przez Ministerstwo Kultury i Dziedzictwa Narodowego. 
2. Uznawanie negatywnych zjawisk na rynku, takich jak fałszerstwa i niedozwolone gry rynkowe, za przejaw jego niedojrzałości i wiara w możliwości samoeliminacji tych zjawisk wraz z jego rozwojem. W Polsce jest wysoki poziom nielegalnego handlu dziełami sztuki za pośrednictwem „działaczy”, którzy prowadzą handel dziełami sztuki bez jakiejkolwiek formy organizacyjnej, co powoduje straty finansowe i wizerunkowe dla rynku.

3. Uznawanie polskiego rynku sztuki za fragment rynku światowego. To stwierdzenie może być prawdziwe jedynie w odniesieniu do ogólnych mechanizmów ekonomicznych, ale już nie np. do struktury sprzedaży dzieł sztuki. Rynek sztuki w Polsce jest rynkiem rodzimym pod względem podmiotów na nim funkcjonujących (zarówno sprzedających, wśród których brak gigantów czy nawet średniaków europejskich, jak i kupujących) oraz przedmiotów (w 90\% dominuje handel dziełami sztuki polskiej, zupełnie brak jest obecnie zainteresowania zakupami sztuki światowej ze strony Polaków, a wobec braku podaży polskiej dobrej sztuki dawnej i współczesnej szansą dla rodzimego rynku jest jedynie sztuka nowoczesna, względnie otwarcie się kolekcjonerów, a w konsekwencji pośredników, na sztukę europejską czy światową). 4. Znacząca liczba podmiotów na rynku (zarówno sprzedających, jak i kupujących). W rzeczywistości ich liczba jest raczej skromna, co wynika z ciągle niewielkiej zamożności w porównaniu do krajów Europy Zachodniej, niskiej świadomości efektu dodanego przy zakupie dzieł sztuki, braku jakichkolwiek zachęt ze strony państwa w postaci ulg podatkowych.

5. Atrakcyjność finansowa - „dzieła sztuki najlepszą inwestycją”. Jest ona pozorna, gdy weźmiemy pod uwagę problem płynności dzieł sztuki i sporej wrażliwości, także pozaekonomicznej - prawnej i społecznej (moda i preferencje).

6. Traktowanie jako wspólnego całego rynku sztuki. W jego poszczególnych segmentach sytuacja ekonomiczna (w tym „głębokość i wycena rynku”, podaż i popyt) i perspektywy są zdecydowanie różne. Najlepiej funkcjonuje w Polsce rynek bibliofilski i numizmatyczny, na nich właśnie występuje najmniej niepożądanych zjawisk, względnie są one skuteczniej eliminowane niż np. na rynku malarstwa. Rynku fotografii nie udało się skutecznie jeszcze w Polsce stworzyć, choć było kilka prób, szczególnie w ciągu ostatnich 10 lat. Jeszcze gorzej prezentują się: rynek rzeźby, którego praktycznie nie ma nie tylko z racji braku kupujących, lecz dobrych dzieł sztuki, rynek mebli czy sztuki użytkowej, który triumfy finansowe święcił w latach 90. XX w. 7. Uznawanie rynku sztuki za silny kapitałowo. Tymczasem dominuje na nim sprzedaż komisowa, prawie brak na nim dużych inwestorów kapitałowych, instytucjonalnych (muzea).

Rynek dzieł sztuki w Polsce, jak i sam obrót dobrami kultury z perspektywy zainteresowania organów ścigania pozostaje obecnie w zasadzie poza działaniami organów państwa, takich jak: Policja, prokuratura, Krajowa Administracja Skarbowa, Centralne Biuro Śledcze czy Agencja Bezpieczeństwa Wewnętrznego. Sprawy w tym zakresie prowadzone przez niniejsze organy mają charakter incydentalny, a bardzo często stanowią dla nich problem z racji braku odpowied- 


\section{ARTYKUtY}

Wojciech Szafrański

nio przygotowanych kadr. Uznawane są bowiem za peryferyjne na tle priorytetowych dla organów ścigania spraw, a jednocześnie wymagają specjalizacji czy nawet tworzenia odpowiednich zespołów (praktyka znana i skuteczna w Francji, Włoszech, Hiszpanii) oraz nakładów środków, co utrudnia podjęcie nie tyle decyzji o powołaniu takich zespołów, ile utrzymywania stałego takich podmiotów.

Z uwagi jednak na postępującą komercjalizację rynku sztuki (aspekt tezauryzacyjny - dzieła sztuki jako element lokaty kapitału) i specyfikę reguł nim rządzących organom ścigania trudno nawet identyfikować przestępstwa na tym rynku, a w konsekwencji ścigać ich sprawców, co powoduje, że rynek ten staje się coraz lepszym miejscem dla działań nie tylko przestępczości tzw. pospolitej, ale i zorganizowanych grup przestępczych czy rozwoju nowych form nielegalnych działań. Tym samym zasadne jest postrzeganie rynku sztuki nie tylko z perspektywy wyłącznie karnoprawnej przestępczości, ale i wskazanie na zjawiska patologiczne, które stanowią zagrożenie dla stabilności i wiarygodności tego rynku, a tym samym łączą się ściśle z naruszeniem reguł należytej staranności w obrocie dziełami sztuki.

Rozpoznanie i znajomość wszystkich mechanizmów funkcjonujących na rynku sztuki jest praktycznie niemożliwe, funkcjonuje on bowiem w ciągłej płynności i ewoluuje. Dodatkowo jest zbudowany na specyficznych zasadach, które powodują, że w coraz większym stopniu staje się on idealnym wręcz miejscem dla działalności przestępczej. Idealnym nie tylko z powodów samych przedmiotów obrotu, co do niedawna uchodziło za jego siłę w świecie przestępczym, gdyż to właśnie za pomocą dzieł sztuki - jako nietracących na wartości - zabezpieczano inne nielegalne transakcje w obszarze handlu, np. narkotykami czy bronią. Rynek sztuki stał się idealny z uwagi na posiadanie tzw. warunków wstępnych dla większej skuteczności działalności przestępczej. Zjawiska powstałe przy tych warunkach są w małym stopniu możliwe do wyeliminowania przez regulacje prawne, gdyż:

a) należą do kultury rynku sztuki wyznaczającego jego specyfikę i dodatkowo mieszczą się w sferze mentalno-behawioralnej jego uczestników,

b) wynikają z podejścia organów ścigania (wymiaru sprawiedliwości) i ich specyfiki organizacyjnej.

Do pierwszej grupy należy zaliczyć:

1. Powszechną asymetrię informacji na rynku sztuki. Jest ona efektem gigantycznego poziomu dostępnych danych, które są generowane przez podmioty uczestniczące bezpośrednio w obrocie dziełami sztuki oraz podmioty z otoczenia bliższego i dalszego rynku sztuki ${ }^{3}$. Dodatkowo dochodzą do tego takie elementy, jak choćby zróżnicowany poziom doświadczenia podmiotów występujących na rynku, istnienie tzw. słabych i mocnych oferentów o różnej skłonności do ryzyka czy dynamika preferencji kupujących, sprzedających i pośredników. Asymetria informacji na ryn-

3 Ekonomiczne aspekty asymetrii aukcji opisane zostały m.in. w: E. Maskin, J. Riley, Optimal Auctions with Risk Averse Buyers, „Econometrica” 1984, nr 52, s. 1473-1518; idem, Asymmetric Auctions, „Review of Economic Studies" 2000, nr 67, s. 413-438. 
ku sztuki dotyczy przede wszystkim: cen, pochodzenia obiektów i ich autentyczności, poziomu zainteresowania i zbioru możliwych strategii, wiedzy o informacji w posiadaniu rywali i wreszcie położenia rywali w zbiorze informacyjnym. Praktycznie żaden z aktorów rynku sztuki nie ma pełnej wiedzy, gdyby jednak założyć, że w modelowym układzie występują jedynie trzy podstawowe grupy: nabywców, pośredników i zbywców, to właśnie pośrednicy dysponują największą wiedzą o mechanizmach rynkowych, a więc w dostępie do zbioru informacji mają przewagę nad pozostałymi aktorami. Uczestnicy rynku sztuki nie są w stanie przełamać asymetrii informacji i tym samym przesunąć się bliżej efektywności rynku, którego właśnie podstawową zdolnością jest zapewnienie niezawodnej informacji przy rozsądnych kosztach, które mogą ponieść zarówno sprzedający, jak i kupujący. Paradoksalnie nawet tym dwóm stronom nie zależy na efektywności rynku, bo każda docelowo chce skorzystać z jego nieefektywności. W procesie obrotu dziełami sztuki następuje bowiem częsta zamiana ról - ktoś z nabywcy staje się zbywcą, chcącym zrealizować swoje oczekiwania co do wzrostu cen na dane dobro, a realizować je można tak naprawdę dopiero przez sprzedaż dzieła sztuki.

2. Hermetyczność rynku - nie jest ona ustanawiana sztucznie przez budowanie barier w ramach otoczenia prawno-ekonomicznego, ale jest procesem naturalnym. Dostęp do kolejnych poziomów rynku, rozumianych jako przewaga informacyjna nad rywalami, możliwy jest bowiem nie poprzez zwiększenie zaangażowania finansowego przez dany podmiot, ale wzrost znaczenia podmiotu w kamaryli rynkowej, którą w głównej mierze tworzą najważniejsi pośrednicy na rynku, a bardzo rzadko sprzedający czy kupujący ${ }^{4}$. Oznacza to, że zamożni klienci na rynku wcale nim nie rządzą. Hermetyczność rynku polskiego pokazuje także nieudany proces art bankingu w latach 1990-2008, co świadczy o porażce pośrednictwa instytucjonalnego W "sztuce inwestowania w sztukę".

3. Kulturę niewiedzy nabywców - oznacza to, że kupujący nieświadomie lub świadomie nie interesuje się mechanizmami rynkowymi i pochodzeniem obiektów, wierząc pośrednikom, traktując ich jako profesjonalistów i obdarzając zaufaniem (także w zakresie poufności informacji o wydatkowanych przez kupującego środkach na dzieło sztuki). Kultura niewiedzy nabywców nie oznacza, że kupujący nie chcą znać np. proweniencji obiektów, ale to, że przyjmują informacje i zapewnienia pośredników, prawie ich nie weryfikując $w$ momencie zawierania transakcji handlowych. Działa prosty mechanizm - „gdybym nie ufał pośrednikowi, tobym u niego nie kupował", a dzieła sztuki są dobrami wyjątkowymi (kolejny mit rynku sztuki) i obrót nimi nie wymaga specjalnego rozgłosu (chyba że ma być celowy - na potrzeby marketingowe). Tym samym kultura niewiedzy nabywców doskonale współgra $z$ kulturą samoobrony pośredników i „normą tajemnicy”.

4. Kulturę samoobrony pośredników - sprowadza się ona do niekupowania przez uczciwych pośredników obiektów o nieznanym lub podejrzanym pochodzeniu oraz

4 Do wyjątków należą niektórzy kolekcjonerzy albo eksperci. 


\section{ARTYKUtY}

Wojciech Szafrański

nieinformowaniu właściwych organów przez pośredników o innych nieuczciwych zachowaniach na rynku sztuki, co jest efektem braku wiary w indywidualne czyszczenie rynku z takich obiektów czy patologii, a wiąże się dodatkowo (zdaniem pośredników) z dużymi kosztami czasowymi i tym samym ekonomicznymi (składanie zeznań na policji, sprawa sądowa itd.), bez pewności efektu zwrotnego w postaci uzdrawiania rynku sztuki.

5. Tak zwaną normę tajemnicy - traktowana jest ona jako tradycja rynku sztuki i rozumiana jako zespół niepisanych reguł poufności dotyczących cen, obiektów i podmiotów na rynku. Tym samym ułatwia to tworzenie nowych wartości dzieł sztuki i trendów na rynku przez pośredników za pomocą ekspertów pracujących na ich zlecenie. Tylko pozornie norma tajemnicy jest łamana poprzez upublicznianie wyników sprzedażowych np. na aukcjach. W rzeczywistości gry rynkowe tak bardzo zmieniają te wyniki, że notowania publiczne nie dają rzeczywistego obrazu liczby i wysokości transakcjis.

6. Powszechną akceptację dla mitów na rynku sztuki - szczególnie niebezpieczne z punktu widzenia nowych zjawisk w obrębie przestępczości na rynku sztuki są: mit legalnego i nielegalnego rynku (czarnego i białego) jako spolaryzowanych i przeciwstawnych sobie, mit nieustannego rozwoju rynku czy mit młodego rynku' 6 . Ten ostatni wspiera patologie, wszelkie bowiem nadużycia na nim występujące tłumaczone są jako przejściowe i możliwe do wyeliminowania wraz z jego rozwojem, przy braku ingerencji ze strony państwa. Szersze wkroczenie ustawodawcze w taki rynek właśnie z racji jego „młodości” jego uczestnicy (tu: pośrednicy) uznają za drogę prowadzącą do jego zadławienia. W rzeczywistości mit młodego rynku jako uzasadnienie dla dziwnych zjawisk na nim (niewiarygodnych cen, sprzedaży na rzecz kupującego, aukcji zamkniętych, brak systemu eksperckiego, nieokreślonej odpowiedzialności podmiotów handlujących dziełami sztuki itp.) umacnia patologię i sprzyja relatywizmowi obrotu. 7. Traktowanie patologii występujących na rynku sztuki jako jego specyfiki brak rozróżnienia, co jest patologią, a co specyfiką rynku sztuki powoduje, że zarówno część uczestników rynku sztuki, jak i podmioty w nim nieuczestniczące otrzymują zafałszowany obraz rynku. Generalnie dla obywatela ma on charakter peryferyjny („mnie nie dotyczy”) i obejmuje tylko ludzi zamożnych, bawiących się na aukcjach, którzy nie mają co robić z pieniędzmi?. Intuicyjne pojmowanie rynku sztuki, bez wyraźnego wskazywania przez specjalistów i opisywania mechanizmów na nim występujących, umacnia brak rozróżnienia specyfiki sektorowej rynku sztuki i patologii, z czego skwapliwie korzystać mogą przestępcy.

5 Często obiekty, które w rzeczywistości są niesprzedane, funkcjonują w notowaniach aukcyjnych jako sprzedane. Zob. W. Szafrański, Handel dziełami sztuki w Polsce a gry rynkowe - zarys problematyki, w: W. Kowalski, K.Zalasińska (red.), Rynek sztuki. Aspekty prawne, Wolters Kluwer Polska, Warszawa 2011, s. 237-247.

6 Na temat mitów na rynku sztuki patrz szerzej: W. Szafrański, Mity i patologie obrotu dziełami sztuki, „Santander Art and Culture Law Review" 2015, nr 1, s. 138-152.

7 Najczęściej formułowana odpowiedź w ramach sondy ulicznej przeprowadzonej w Poznaniu w dniach 10-18.04.2015 r. (na grupie 121 osób). 
Do drugiej grupy zalicza się:

1. Skomplikowanie spraw, co przekłada się na poziom absorbowania ludzi i środków do skutecznej walki z przestępczością w obszarze rynku sztuki, a jednocześnie nie gwarantuje dobrego wyniku spraw rozwiązanych przez organy ścigania.

2. Peryferyjność na tle priorytetowych dla organów ścigania spraw8.

3. Eksperckość na każdy etapie. Już w ramach wstępnego wykrywania przestępstw w obszarze rynku sztuki konieczne jest rozpoznanie nie tylko osobowe, ekonomiczno-finansowe czy terenowe, ale przede wszystkim sektorowe9. Przekłada się to jednocześnie na dwa niezależne od siebie elementy. Szkolenie i specjalizacja kadr w zakresie ścigania przestępstw na rynku sztuki (czy w obszarze dziedzictwa) wymagają czasu, środków i konsekwentnie realizowanego programu utrzymywania takich jednostek. W praktyce będzie to mała grupa ludzi wyspecjalizowanych, którymi nie powinny rządzić jedynie statystyka i medialność (sukcesy obrazowane poprzez wartości lub liczby). W rzeczywistości niestety wpływają one na funkcjonowanie takich jednostek w stopniu większym niż na inne jednostki. Te jednostki, komórki, grupy eksperckie w ramach kolejnych zmian są rozwiązywane lub włączane do innych struktur, co powoduje przesunięcie ich dotychczasowych zadań na drugi plan ${ }^{10}$. Ponadto brak wyspecjalizowanych jednostek (ludzi) powoduje, że możliwość monitorowania rynku sztuki z perspektywy możliwości „przestępczych” oraz skutecznego ścigania jest bardzo mała albo ma charakter przypadkowy.

Opisane wyżej warunki wstępne charakterystyczne dla rynku sztuki powodują, że powstają coraz to nowe zjawiska w obrębie przestępczości na rynku sztuki w Polsce. Nie zawsze są one kopiowane z praktyki innych państw, nieraz są wytworem rodzimym z uwagi na specyficzne otoczenie prawno-ekonomiczne (brak rejestracji handlowych albo ich ograniczony zasięg w związku $z$ wprowadzeniem tzw. ksiąg ewidencyjnych w 2017 r., względnie niewykorzystywanie mechanizmu, które daje prawo).

\footnotetext{
8 Wskazał na to W. Pływaczewski, Pranie pieniędzy oraz inne nielegalne transakcje finansowe z perspektywy międzynarodowego rynku dzieł sztuki, w: E.W. Pływaczewski (red.), Proceder prania pieniędzy i jego implikacje, Wolters Kluwer Polska, Warszawa 2013, s. 180.

9 Podobnie jest w przypadku przestępstw z zakresu prania brudnych pieniędzy - zob. W. Jasiński, System przeciwdziałania i zwalczania prania pieniędzy, w: E.W. Pływaczewski (red.), op. cit., s. 84-87.

10 W 2007 r. w ramach Komendy Głównej Policji (KGP) utworzono Krajowy Zespół do Walki z Przestępczością przeciwko Dziedzictwu Narodowemu, zajmujący się m.in. analizowaniem zagrożeń przestępczością przeciwko dziedzictwu, wypracowywaniem skutecznych sposobów wykrywania ich sprawców oraz ujawniania i zwalczania takich przestępstw, współpracą z Centralnym Biurem Śledczym KGP. Jednocześnie utworzono w kilku komendach wojewódzkich kilkuosobowe zespoły do zwalczania przestępczości przeciwko dziedzictwu narodowemu. W latach 2011-2013 stałe wojewódzkie zespoły zostały zlikwidowane, ze szkodą dla skuteczności wykrywania przestępstw związanych z dziełami sztuki. Ponowne podpisanie porozumienia między Ministerstwem Kultury i Dziedzictwa Narodowego a Komendą Główną Policji w 2018 r. zapoczątkowało utworzenie kolejny raz struktur i współpracę w zakresie przeciwdziałania i ścigania przestępczości przeciw dziedzictwu.
} 


\section{ARTYKUtY}

Wojciech Szafrański

\section{Rynek sztuki a ochrona dziedzictwa - zarys stanu obecnego}

„Samobudujący się” przez ostatnie 30 lat rynek sztuki w Polsce funkcjonuje nie tylko bez specjalnego wsparcia ze strony państwa, ale także bez widocznego zainteresowania ze strony decydentów politycznych i z licznymi niezrealizowanymi pomysłami legislacyjnymi, począwszy od swobody obrotu, poprzez modele mieszane, aż do reglamentacji. Niedługi, z perspektywy państw Europy Zachodniej, czas funkcjonowania rynku w Polsce jest mierzalny, ale mechanizmy, które się na nim wytworzyły, często odmienne od tych występujących na rynkach dojrzałych, już na tym początkowym etapie doprowadziły do szybkiego zaniku jego transparentności i naruszenia dwóch elementarnych oznak jego „zdrowia”, tj. autentyczności obiektów oraz wiarygodności cen.

Nie ulega wątpliwości, że ową transparentność będzie trzeba sukcesywnie odbudowywać za pomocą hard law (czyli działań ustawodawcy wspierających eliminację niepożądanych zjawisk na rynku sztuki - patrz niżej) oraz soft law (tworzonych przez powstające na rodzimym rynku sztuki organizacje zawodowe czy instytucje zrzeszające kupujących lub sprzedających). Przy tak ostro zarysowanej ocenie polskiego rynku sztuki należy pamiętać, że nie przeszedł on takiej ewolucji jak zachodnie rynki sztuki, na których funkcjonują wielopokoleniowe kolekcje, hierarchia podmiotów sprzedających czy pośredniczących w handlu dziełami sztuki, tylko bardzo szybko został wprzęgnięty w przemysł sztuki wraz z wszystkimi tego konsekwencjami: przewagą podaży nad popytem, marketingiem relacyjnym, art bankingiem, art indeksami, stopami zwrotu, rankingami artystów itp.

Ustawodawstwo dotyczące różnych elementów ochrony dziedzictwa kulturowego zaczęło przyrastać w Polsce w ciągu ostatnich 15 lat. Jest to efekt nie tylko przyjmowania regulacji międzynarodowych czy europejskich w tym zakresie (a i tu obserwowana jest tendencja wzrostowa, wynikająca ze zwiększania stopnia zainteresowania ochroną dziedzictwa), ale także faktycznego przyrastania dziedzictwa, konieczności jego kategoryzowania celem zapewnienia jego ochrony i finansowania, jak i samej polityki kulturalnej państwa. Uchwalanie nowych ustaw w tym zakresie, liczne nowelizacje podstawowej ustawy o ochronie zabytków i opiece nad zabytkami ${ }^{11}$, a tym samym budowanie nowych form ochrony, wprowadzanie nowej terminologii (tworów sztucznych - niewykazujących należytego stopnia powiązania) - użytkowej w danym momencie, ale komplikującej przejrzystość regulacji rynku, skutkują tym, że całość regulacji tylko w założeniu stanowi zwarty system ochrony dziedzictwa, a w rzeczywistości jest konglomeratem ustaw i aktów niższego rzędu, który jest powiązany w sposób luźny z uwagi na intuicyjnie rozumiany przedmiot ochrony. W rzeczywistości brak jest ustalenia jego klasyfikacji i uporządkowania definicji legalnych poprzez zakreślenie rzeczywistych granic pojęciowych ${ }^{12}$. Stan taki dotyczy też rozporządzeń, gdyż są przygotowywane bardziej

11 Ustawa z dnia 23 lipca 2003 r. o ochronie zabytków i opiece nad zabytkami, tekst jedn. Dz. U. z 2017 r., 12 Zob. także projekt założenia do ustawy - M. Drela, Miejsce ochrony zabytków ruchomych w systemie ochrony dziedzictwa kulturowego [niepubl.]. 
do konkretnej ustawy, bez głębszej refleksji, że one również w ogólności winny być spójne z naczelnymi zasadami systemu ochrony dziedzictwa.

Obecnie obowiązujące regulacje dotyczące obrotu zabytkami, znajdujące się w następujących aktach prawnych rangi ustawy ${ }^{13}$ :

- ustawie z dnia 23 lipca 2003 r. o ochronie zabytków i opiece nad zabytkami,

- ustawie z dnia 21 listopada 1996 r. o muzeach ${ }^{14}$,

- ustawie z dnia 14 lipca 1983 r. o narodowym zasobie archiwalnym i archiwach $^{15}$,

- ustawie z dnia 20 lutego 2015 r. o rzeczach znalezionych ${ }^{16}$,

- ustawie z dnia 25 maja 2017 r. o restytucji narodowych dóbr kultury ${ }^{17}$, stanowią efekt obostrzeń wynikających z ograniczeń nałożonych na właścicieli zabytków/dóbr kultury, zróżnicowanych z zależności od kategorii zabytku oraz form jego ochrony prawnej. Zarówno ochrona dziedzictwa, jak i rynek sztuki w Polsce z perspektywy regulacji prawnych (zainteresowania ustawodawcy), a przede wszystkim ich praktycznego funkcjonowania znajdują się ciągle w stadium rozwoju.

Dla obszaru rynku sztuki i ochrony dziedzictwa charakterystyczne jest również niedostrzeganie przez decydentów politycznych, a w konsekwencji ustawodawcę, wzajemnych związków między rynkiem a ochroną dziedzictwa, ewentualnie zauważanie jedynie zagrożeń dla dziedzictwa, wypływających z funkcjonowania rynku głównie w zakresie spraw wywozowych, przy zupełnym niedostrzeganiu elementów korzystnych. Taki stan rzeczy to efekt braku elementarnej wiedzy o funkcjonowaniu rynku sztuki i formach ochrony zabytków, co prowadzi do nieprzewidywania wszystkich skutków uchwalanych zmian z obszaru ochrony dziedzictwa dla rynku sztuki, w tym: artystów, podmiotów handlujących zabytkami i kolekcjonerów (właścicieli prywatnych zabytków). Przykłady można mnożyć, spoglądając na same tylko nowelizacje, względnie dyskusje toczące się przy

\footnotetext{
13 Pełny ich wykaz znajduje się w: W. Szafrański, Obrót zabytkami ruchomymi, w: K. Zeidler (red.), Raport dotyczący stanu ochrony prawnej oraz kierunków zmian w zakresie prawnej ochrony zabytków ruchomych w Polsce, przygotowany w ramach Krajowego Programu Ochrony Zabytków i Opieki nad Zabytkami na lata 2014-2017 dla Narodowego Instytutu Muzealnictwa i Ochrony Zbiorów, Gdańsk 2016, s. 148-150. W stosunku do stanu tam przedstawionego należy wskazać dodatkowo ustawę z dnia 25 maja 2017 r. o restytucji narodowych dóbr kultury (Dz. U. poz. 1086), wprowadzającą zmianę w ustawie z dnia 23 lipca 2003 r. o ochronie zabytków i opiece nad zabytkami (Dz.U. nr 162, poz. 1568) dotyczącą ksiąg ewidencyjnych oraz rozporządzenie Parlamentu Europejskiego i Rady (UE) 2019/880 z dnia 17 kwietnia 2019 r. w sprawie wprowadzania i przywozu dóbr kultury, Dz. Urz. UE L 151 z 7.06.2019 r. (nie jest jeszcze implementowane do polskiego systemu prawnego).

14 Ustawa z dnia 21 listopada 1996 r. o muzeach, tekst jedn. Dz. U. z 2018 r., poz. 720.

15 Ustawa z dnia 14 lipca 1983 r. o narodowym zasobie archiwalnym i archiwach, tekst jedn. Dz. U. z 2018 r., poz. 217.

16 Ustawa z dnia 20 lutego 2015 r. o rzeczach znalezionych, Dz. U. poz. 397.

17 Ustawa z dnia 25 maja 2017 r. o restytucji narodowych dóbr kultury, Dz. U. poz. 1086.
} 


\section{ARTYKUtY}

Wojciech Szafrański

ich uchwalaniu w komisjach sejmowych. Przejawem niedostrzegania wzajemnych związków rynku sztuki i dziedzictwa może być:

1. Brak skutecznego mechanizmu pozwalającego ścigać przede wszystkim fałszerzy z racji pozostawienia do dyspozycji policji i prokuratury jedynie art. 286 Kodeksu karnego ${ }^{18}$ (oszustwa) wymagał naprawdę pilnych zmian. Wprowadzenie do ustawy o ochronie zabytków i opiece nad zabytkami - w wyniku nowelizacji tej ustawy z 24.02.2006 r. - dwóch artykułów, tj. art. 109a i 109b, nie stało się skutecznym narzędziem w walce $z$ fałszerstwami dzieł sztuki i handlem nimi. Największym problemem, którego nie udało się rozwiązać przez wprowadzenie nowych regulacji, był brak odpowiedzialności osoby, która tylko podejrzewa, że zabytek jest podrobiony czy przerobiony, a i tak go zbywa. W praktyce bowiem organy ścigania muszą wykazać, że osoba taka wiedziała o podrobieniu lub przerobieniu, a nie tylko podejrzewała, że obiekt może być przerobiony bądź podrobiony. Z takiego stanu rzeczy chętnie korzystają zarówno nieuczciwi handlarze (osoby prywatne, tzw. działacze czy antykwariusze), jak i prowadzący wydawałoby się rzetelnie handel dziełami sztuki, którzy jednak często wobec braku towaru poszukiwanego na rynku decydują się na przyjęcie do sprzedaży prac „prawie” np. Władysława Strzemińskiego czy Jacka Malczewskiego. W dalszych działaniach legislacyjnych, tzw. wspierających, brak było konsekwencji, np. regulacji rynku ekspertów i ekspertyz, eliminacji fizycznej lub „symbolicznej” falsyfikatów, działań szkoleniowych, stworzenia warunków do działalności stowarzyszeń i tworzenia soft law, by można mówić o prowadzeniu spójnej polityki i dostrzeganiu związków między rynkiem a ochroną dziedzictwa. 2. Brak zrozumienia przez ustawodawcę związków zauważalny jest na poziomie podmiotowym. Na rynku podmioty te występująjako kupujący - nabywcy (kolekcjonerz ${ }^{19}$ ), a w systemie ochrony dziedzictwa określani są jako właściciele prywatni zabytków. Dzieje się tak z uwagi na szeroką definicję zabytku w prawie polskim oraz postawienie przez ustawodawcę polskiego na szeroką ochronę zabytków, zbyt - moim zdaniem - daleko idącą w porównaniu do możliwości faktycznych i finansowych państwa. Niestety mnożą się pomysły i projekty nowelizacyjne, w których autorzy nie odnoszą się do wydmuszkowego prawa „zabytków prywatnych”, wynikającego z ofensywy przepisów administracyjnoprawnych (czy dodatkowo zwiększającej się roli prawa autorskiego ${ }^{20}$ ). Dodatkowo nowelizacje powstają pod wpływem bieżących sytuacji, czego przykładem może być konstrukcja Listy Skarbów Dziedzictwa.

\footnotetext{
18 Ustawa z dnia 6 czerwca 1997 r. Kodeks karny, tekst jedn. Dz. U. z 2018 r. poz. 1600, 2077.

19 Większość kupujących na rynku sztuki w Polsce cały czas deklaruje, że robi to z pobudek emocjonalnych, a w mniejszym stopniu z pobudek czysto ekonomicznych (Rynek sztuki. Sztuka rynku - raport Deloitte z kwietnia 2013, s. 14, http://rynekisztuka.pl/wp-content/uploads/2013/04/pl_artbanking_pl.pdf [dostęp: 1.02.2019]). Pobudki emocjonalne są z pewnością istotne, zważywszy na zupełny brak zainteresowania ustawodawcy kolekcjonerami i niedostrzeganie ich znaczenia dla kultury.

20 Rola prawa autorskiego nie jest w niniejszym tekście analizowana - patrz szerzej: I. Szmelter, W. Kowalski, Wystawiennictwo sztuki nowoczesnej a ochrona integralności utworów, "Muzealnictwo" 2008, nr 49, s. 20-41; W. Szafrański, Upublicznianie kolekcji prywatnych w Polsce. Problemy prawne w praktyce, w: P. Stec (red.), Kolekcje - wystawy - muzealia. Problematyka prawna, Redakcja Wydawnictw Wydziału Teologicznego Uniwersytetu Opolskiego, Opole 2015, s. 63-78.
} 
W rzeczywistości należy spojrzeć na rynek sztuki i ochronę dziedzictwa poprzez tożsame elementy, tj.:

1. Sprzedającego i kupującego na rynku, czyli właściciela publicznego i prywatnego zabytku w ochronie dziedzictwa. Szczególnie interesująca jest tu rola tego ostatniego. Dziś zabytek ruchomy czy zabytek archeologiczny bardziej stanowi problem niż wymierną korzyść dla właściciela prywatnego (pomijając element emocjonalny) i stan ten raczej się pogłębia. Właściciele prywatni skutecznie starają się bronić przed instrumentami ściślejszej ochrony administracyjnoprawnej. Ograniczenia i nałożone obowiązki w przypadku wpisu od rejestru tylko odstraszają od dokonania wpisu. Paradoksalnie ustawa o ochronie dóbr kultury z $1962 \mathrm{r}^{21}$ bardziej "ceniła" kolekcjonerów niż dzisiejsza ustawa o ochronie zabytków i opiece nad zabytkami. Przy całkowicie odmiennym ustroju i konstrukcji własności przewidywała instytucję kolekcji i (choćby na papierze) wsparcia dla kolekcjonerów (choćby przy wpisie do rejestru) ${ }^{22}$. Kilku kolekcjonerów dzieł sztuki śledzących z uwagą zapowiedzi zmian w prawie ochrony dziedzictwa jeszcze w 2013 r. myślało o przeniesieniu części kolekcji poza granice Polski z obawy przed wprowadzeniem wpisu z urzędu do rejestru zabytków i niemożliwością wywozu takich obiektów, wedle informacji autora. Być może byłby to krok zbyt daleko idący, ale takie zapowiedzi i nowelizacja ustawy o ochronie zabytków i opiece nad zabytkami z września 2013 r. osłabiają stopień zaufania owych nabywców (kolekcjonerów) do państwa z uwagi na systematyczne „drążenie” prawa własności za pomocą regulacji prawnoadministracyjnych. Oczywiście istnieją realne niebezpieczeństwa dla dziedzictwa kulturalnego i naturalnego wynikające z funkcjonowania rynku sztuki i tzw. złych kolekcji (np. archeologicznych, zoologicznych). Istnieje także wiele wspólnych zagrożeń, np. kradzieże i niekorzystne regulacje prawne z tytułu możliwości nabycia zabytku skradzionego (wielokrotnie wskazywane $w$ literaturze przedmiotu) ${ }^{23}$ czy falsyfikaty. Nikt $z$ decydentów politycznych nie zlecił przeprowadzenia analizy zysków i strat funkcjonowania polskiego rynku sztuki w aspekcie ochrony dziedzictwa, nie można nawet odnaleźć jakiekolwiek refleksji w tym zakresie. Korzyści płynące z funkcjonowania rynku sztuki są także znaczące, choć nie tak proste do ukazania liczbowego. Z uwagi na mniej wymierny charakter są często pomijane w argumentacji w toku procesu legislacyjnego. A przecież funkcjonowanie rynku sztuki i powstawanie nowej klasy kolekcjonerów (nabywców i tym samym często właścicieli prywatnych zabytków) mają swoje odbicie w rosnącym poziomie świadomości ochrony dziedzictwa, któ-

\footnotetext{
21 Ustawa z dnia 15 lutego 1962 r. o ochronie dóbr kultury, Dz. U. Nr 10, poz. 48.

22 Zob. rozdział IX ustawy z dnia 15 lutego 1962 r. o ochronie dóbr kultury.

23 Zob. W. Kowalski, Prawo ochrony zabytków w świetle aktualnych problemów zachowania dziedzictwa kulturowego Polski, w: W. Szafrański, K. Zalasińska (red.), Wokół problematyki prawnej zabytków i dzieł sztuki, t. 3 , Wydawnictwo Poznańskie, Poznań 2009. Znaczącym krokiem jest upubliczniony krajowy wykaz zabytków skradzionych lub wywiezionych za granicę niezgodnie z prawem, prowadzony wcześniej przez Narodowy Instytut Muzealnictwa i Ochrony Zbiorów a obecnie przez Departament Dziedzictwa Kulturowego za Granicą i Strat Wojennych, https://skradzionezabytki.pl/i/\#/ [dostęp: 21.04.2019].
} 


\section{ARTYKUEY}

Wojciech Szafrański

rego w żadne sposób nie można przełożyć na język przepisów. Zauważalne korzyści to m.in.: powrót poloników, miejsca pracy (w Polsce w zakresie handlu dziełami sztuki przeważają małe podmioty, zatrudniające 2-3 pracowników, których jednak ciągle jest sporo), wsparcie dla artystów poprzez zakupy na rynku, co wobec dość nieuporządkowanej polityki państwa odnośnie do ubezpieczeń twórców itp. jest dość istotne ${ }^{24}$, zdejmowanie pewnego ciężaru z państwa poprzez udział (także finansowy) w promocji kultury polskiej, współpraca kolekcjonerów z muzeami (możliwości budowania wspólnej narracji sztuki; wiele kolekcji skutecznie uzupełnia zbiory publiczne bez zauważalnej rywalizacji, a więc zgoła inaczej, niż ma to miejsce w innych krajach - problem tzw. muzeów prywatnych), projekty związane z upublicznianiem kolekcji i tym samym zwiększający się dostęp („konstytucyjny”) do dziedzictwa kulturalnego, akcje ratunkowe kolekcjonerów dotyczące spuścizny artystów, współfinansowanie wystaw ${ }^{25}$.

2. Dzieło sztuki (obiekt) - przedmiot obrotu rynkowego, zabytku będącego kategorią prawną w systemie ochrony dziedzictwa w Polsce. Pozostawiając na marginesie szczegółowe rozważania dotyczące pojęcia prawnego zbytku i właściwie pozaprawnego dzieła sztuki, jak i w ogóle zamieszania terminologicznego wynikającego $z$ funkcjonowania $w$ równych aktach prawnych bardzo różnych terminów i opisowych określeń, z których ustaleniem zakresu pojęciowego mają kłopot nawet organy stosujące prawo (jak policja, prokuratura, sądy czy wojewódzcy konserwatorzy zabytków), a co dopiero zwykły obywatel, nie ulega wątpliwości, że dziś mamy w Polsce coraz większe problemy z utrzymaniem tak szeroko zakreślonej ochrony dziedzictwa. Dlatego postępuje wzmacnianie ochrony niektórych jego elementów, czego dowodem może być Lista Skarbów Dziedzictwa, by ostatecznie odejść od chronienia wszystkiego. Wyraźnie widać to także w zakresie przepisów wywozowych. Polska nie może zrzucić pewnego jarzma tradycji historycznej dotyczącej faktu, że rodzime przepisy dotyczące wywozu kwalifikowane są jako przepisy składające się na system ochrony dziedzictwa, a nie jako element związany z obrotem towarami ${ }^{26}$. Takie spojrzenie unaoczniłoby rzeczywiście związki ochrony dziedzictwa z rynkiem sztuki.

3. Muzea jako element systemu ochrony dziedzictwa i jednocześnie ważny podmiot na rynku sztuki. W tym aspekcie muzea odgrywają poczwórną rolę:

a) kupującego - muzea rejestrowane korzystają tym samym z preferencyjnych regulacji, tj. prawa pierwszeństwa i prawa pierwokupu (art. 20 ustawy o mu-

24 Do niedawna niewielki procent artystów odnosił jakąkolwiek korzyść z funkcjonowania rynku sztuki, rozrost tzw. aukcji promocyjnych albo młodej sztuki otworzył nowy rozdział rynku sztuki w Polsce.

25 Zob. W. Szafrański, Publiczne aspekty prywatnych kolekcji, w: A. Jagielska-Burduk, W. Szafrański (red.), Kultura w praktyce. Zagadnienia prawne, Wydawnictwo Poznańskiego Towarzystwa Przyjaciół Nauk, Poznań 2012, s. 43-58.

26 Zauważyła to w szerszym aspekcie K. Zalasińska, Wpływ zmiany przepisów dotyczacych wywozu zabytków za granice na rynek sztuki w Polsce, w: W. Kowalski, K. Zalasińska (red.), Rynek sztuki. Aspekty prawne, Wolters Kluwer Polska, Warszawa 2011, s. 169 in. 
zeach z 1996 r.), które w obecnej postaci uznać należy za lepiej funkcjonujące od tych zawartych w pierwotnej konstrukcji ustawy o muzeach z 1996 r.;

b) sprzedającego - zgodnie $z$ art. 23 ustawy o muzeach z 1996 r., zarówno muzea państwowe, jak i samorządowe mogą dokonywać zamiany sprzedaży lub darowizny muzealiów, oczywiście w uzasadnionych wypadkach, po uzyskaniu pozwolenia ministra właściwego do spraw kultury i ochrony dziedzictwa i przy założeniu, że środki uzyskane ze sprzedaży zostaną przeznaczone wyłącznie na uzupełnienie zbiorów muzeum. Choć przepis ten w odniesieniu do sprzedaży muzealiów można uznać dziś za raczej „półmartwy”, dobrze, że ciągle funkcjonuje w ustawie. Owa „martwota” stanowi bowiem raczej efekt braku „pierwszego odważnego” niż braku obiektów, które mogłyby być sprzedane (zważywszy na fakt, że w czasach PRL zakupy muzealne często stanowiły rodzaj pomocy dla artystów, a nie konieczność uzupełnienia zbiorów muzealnych dla ciągłości narracji artystycznej), czy braku potrzeb (na rynku pojawia się bowiem coraz więcej obiektów, które chętnie muzea by zakupiły, względnie wykupy depozytów muzealnych, problemem pozostają środki);

c) kształtującego rynek - nie chodzi tu oczywiście o niezgodne z Kodeksem Etyki Muzealników ICOM działania muzeów czy muzealników poprzez tzw. uwikłanie w rynek ${ }^{27}$. W Polsce cały czas, silniej niż ma to miejsce w krajach Europy Zachodniej, istnieje „narracja muzealna” (instytucji publicznych) istotna dla potencjalnych kupujących, a przez to dla sprzedających i pośredników. Wystawy stałe i czasowe, depozyty muzealne są ważniejsze od systemów rankingów, sztucznej mody i są dość skuteczne w ochronie kupujących przed bańkami spekulacyjnymi. W świadomości nabywców w Polsce muzea pozostają wyznacznikiem statusu artysty i swego rodzaju przewodnikiem dla kolekcjonera;

d) eksperta (?) - ta rola nieprzypadkowo została opatrzona znakiem zapytania, ponieważ od dłuższego czasu toczy się w praktyce i literaturze przedmiotu dyskusja nad udziałem muzealników czy muzeów w ocenie autentyczności obiektów, tak istotnej dla zdrowego rynku sztuki. Zauważalne jest tagodzenie rygorystycznych dotąd regulacji etycznych wyrażanych w kodeksach ICOM ${ }^{28}$. Tzw. kodeks seulski z 2004 r. otworzył już częściowo drogę muzeom do wydawania ekspertyz - zgodnie z pkt 5.1, muzeum może podjąć się świadczenia usług w zakresie identyfikacji, nie może jednak osiągać z tego tytuł zysku29. Warto wskazać, że nie oznacza to, iż takiej

27 Zob. także K. Zalasińska, Muzea uwikłane w rynek sztuki, „MOCAK Forum” 2013, nr 1, s. 26-29.

28 Zob. S. Waltoś, Muzealnik jako ekspert na rynku dzieł sztuki, w: R. Pasieczny (red.), Problematyka autentyczności dzieł sztuki na polskim rynku. Teoria, praktyka, prawo, Narodowy Instytut Muzealnictwa i Ochrony Zbiorów, Warszawa 2012, s. 313-322.

29 Ibidem, s. 317-318. 


\section{ARTYKUtY}

Wojciech Szafrański

identyfikacji ma dokonywać za darmo. Z kolei wyceny obiektów muzea, zgodnie z Kodeksem ICOM, mogą dokonywać w celu ich ubezpieczenia na oficjalne żądanie instytucji publicznych, ale z zastrzeżeniem braku możliwości odniesienia korzyści. Zasadną w moim przekonaniu liberalizację w zakresie zasad etyki widać także odnośnie do muzealników, którym Kodeks ICOM obecnie wprost nie zabrania wykonywania ekspertyz, zakazuje tylko (albo aż) rekomendowania komukolwiek spoza muzeum pośrednika, aukcjonera czy eksperta wyceniającego (pkt 8.15), udziału muzealników w obrocie handlowym, którego przedmiotem jest dziedzictwo natury lub kultury (pkt 8.14). Zgodnie z regułą antykonfliktową, muzealnicy nie powinni podejmować innego płatnego zatrudnienia lub przyjmować zleceń na zewnątrz, które pozostawałyby w konflikcie lub mogły zostać uznane za co najmniej pozostające $w$ konflikcie z muzeum $(\mathrm{pkt} 8.13)^{30}$. Ustawa o muzeach z 1996 r., w art. 34 odwołująca się do zasad etyki (wtedy jeszcze restrykcyjnego kodeksu argentyńskiego), zabrania muzealnikom wykonywania ekspertyz „mogących powodować konflikt interesów z zatrudniającym go muzeum", nie ustanawia natomiast wprost całkowitego zakazu wydawania opinii, np. w przedmiocie autentyczności dzieła sztuki. W rozmowach z dyrektorami muzeów w Polsce spotkać się można z całą paletą odpowiedzi na pytanie o zasadność zmiany tego przepisu: począwszy od opcji zaostrzenia jeszcze przepisów i wprowadzenia wprost zakazu, poprzez pozostawienie obecnej regulacji, aż po daleko idącą zmianę stanu, tj. umożliwienie przynajmniej muzeom - jako instytucji posiadającej odpowiednie zaplecze - wydawania ekspertyz dotyczących nie wyceny, lecz autentyczności dzieł sztuki. Pojawia się także myśl o tworzeniu przy muzeach np. fundacji, przez które „przepuszczane” byłby działania eksperckie, a które wspierałyby finansowo działalność muzeów. Liberalizacja w zakresie ekspertyz przede wszystkim muzeów jest uzasadniona nie tylko wobec posiadania odpowiedniego zaplecza przez muzea w Polsce, aspektów finansowych takiej działalności, pata na rynku sztuki (przy braku rozwiązań dotyczących ekspertów), ale też $z$ uwagi na zmieniającą się rolę muzeum (także jako centrum kompetencji). Obecnie transakcje dotyczące ruchomych dóbr kultury obarczone są:

a) ryzykiem dla zbywców i nabywców, wynikających z zarówno ze specyfiki rynku, przedmiotu obrotu ${ }^{31}$, jak i trudności w praktycznym zapobieganiu nielegalnemu obrotowi dobrami kultury i zwalczaniu go ${ }^{32}$; ryzyko to jest

30 Ibidem, s. 318-319.

31 Tu także niska elastyczność popytu.

32 Przedmiotem nielegalnego obrotu dobrami kultury najczęściej są obiekty, którym ustawodawstwo danego państwa poświęca szczególną uwagę (np. zabytki archeologiczne), gdyż tylko bardziej istotne obiekty (znaczącej wartości albo cechujące się niską dostępnością) dają gwarancję rzeczywistej opłacalności finansowej takiego nielegalnego obrotu. Wykorzystywana jest tutaj także niekompatybilność rozwiązań prawnych w poszczególnych państwach UE. 
rekompensowane uczestnikom obrotu brakiem klasycznej substytucyjności takich dóbr, a tym samym specyficznością finansową (inwestycyjność), symboliczną (także jako dóbr dodatnich) i prestiżową ${ }^{33}$;

b) koniecznością utrzymania co najmniej pewnego quantum ograniczeń w obrocie wynikającej z wyjątkowości takich dóbr, rozumianych nie tylko jako rzeczy oznaczone indywidualnie, ale przede wszystkim ocenianych przez pryzmat wartości - jako składających się na dziedzictwo narodowe. Zasadniczo ograniczenia prawa własności w tym zakresie determinują poziom wolności obrotu takimi dobrami. Jednak z racji specyfiki przedmiotu obrotu, jego postępującego różnicowania, wynikającego nie tylko z samej kategoryzacji, ale i form ochrony zabytków (dziedzictwa) w prawie polskim, wskazywana zasada doznaje licznych wyjątków, które są coraz bardziej rozbudowywane pod egidą rozszerzającej się wykładni konieczności ochrony dziedzictwa.

\section{Przestępstwa i patologie istniejące w obrocie zabytkami/dobrami kultury na rynku sztuki w Polsce}

Szczegółowa analiza rynku dzieł sztuki w Polsce, który nie ogranicza się jedynie do samego obrotu zabytkami/dobrami kultury, pozwala uchwycić zjawiska generalnie pomijane $w$ działaniach organów ścigania, które świadczą o postępującym wykorzystywaniu rynku sztuki do różnych działań przestępczych i postępujących (acz zmieniających się) zjawiskach patologicznych na tym rynku. Tym samym rynek, wyodrębniony z uwagi na przedmiot obrotu (czyli zabytki/dobra kultury), z racji specyficznych mechanizmów ekonomicznych i odmiennego otoczenia prawnego (determinowanego nie tylko przez przepisy z zakresu obrotu, ale i ochrony dziedzictwa, przy jednoczesnym braku przepisów dotyczących bezpośrednio rynku sztuki), stanowi doskonałe pole do działalności niezgodnej z prawem.

Najbardziej rozpoznanymi w działalności organów ścigania w Polsce kategoriami przestępstw przeciwko ruchomym dobrom kultury są:

a) kradzież, kradzież z włamaniem, kradzież rozbójnicza, rozbój (wstępnie rozpoznane zjawisko artnappingu),

b) paserstwo.

Także skutecznie lub mniej skutecznie ściągane i rozpoznane przez organy są następujące przestępstwa:

a) przemyt (zabytków/dóbr kultury),

b) oszustwo, którego przedmiotem jest dobro kultury, tu stosowanie art. 286 Kodeksu karnego do zróżnicowanych spraw, np. sprzedaży sfałszowanego dzieła sztuki niebędącego zabytkiem, ale i innych stanów faktycznych (patrz też niżej), 


\section{ARTYKUtY}

Wojciech Szafrański

c) niszczenie zabytku - również niszczenie stanowisk archeologicznych (tzw. wykopki) celem pozyskania obiektów (zabytków archeologicznych) i nielegalnego obrotu,

d) fałszerstwo zabytku i wprowadzanie do obrotu (art. 109a i 109b ustawy o ochronie zabytków i opiece nad zabytkami) - w tym ostatnim przypadku konieczne są jednak zorganizowane działania organów, gdyż generalnie można wskazać jedynie na pojedyncze sukcesy policji czy prokuratury w tym zakresie, nieraz z powodu obiektywnych trudności dowodowych, nieraz z powodu błędów i niewłaściwego przygotowania do tego typu spraw o dużej specyfice i kapitałochłonności.

W zdecydowanie mniejszym stopniu nie tyle występuje na rynku sztuki, ile istnieje w świadomości organów występowanie następujących przestępstw na rynku sztuki, a przede wszystkim skuteczne ich ściganie:

a) łapownictwo poprzez rynek sztuki, bez wiedzy lub za wiedzą podmiotów na rynku sztuki (pośredników),

b) korupcja na rynku sztuki (podmiotowo inna niż w punkcie wyżej) celem uwiarygodniania obiektów (zarówno falsyfikatów, jak i pochodzących z przestępstwa) np. przed ekspertów, przyjmująca w zależności do stanu faktycznego charakter np. poświadczenia nieprawdy, fałszerstwa dokumentów (np. w zakresie fałszerstwa dokumentacji proweniencji, atrybucyjnej),

c) pranie brudnych pieniędzy poprzez nabywanie (względnie zbywanie „bielenie”) zabytków/dóbr kultury,

d) nielegalne transakcje na rynku sztuki, rozumiane jako:

- obrót zabytkami/dobrami kultury stanowiącymi res extra commercium (w momencie ratyfikacji konwencji34, np. należących do podwodnego dziedzictwa archeologicznego),

- obrót zabytkami/dobrami kultury stanowiącymi przedmiot przestępstwa (np. pochodzącymi z kradzieży, falsyfikatów) - tu osobne miejsce w działaniach organów ścigania powinny zajmować tzw. czarne aukcje,

- obrót zabytkami/dobrami kultury, których obrót jest ograniczony, bez uwzględnienia tych ograniczeń (np. zabytków archeologicznych),

e) naruszanie przepisów dewizowych (np. płatność gotówką za granicą za dobra kultury, bez deklaracji wywozu powyżej 10 tys. euro),

f) uszczuplanie należności celno-podatkowych związanych z przywozem dóbr kultury/zabytków w dalszych celach handlowych poprzez fałszowanie atrybucji czy zaniżanie wartości.

Kryminologiczny obraz zjawisk patologicznych obejmowałby także prowadzenie działań mistyfikujących czy innego typu niedozwolonych gier rynkowych, takich jak:

34 Europejska Konwencja o ochronie dziedzictwa archeologicznego (poprawiona), sporządzona w La Valetta dnia 16 stycznia 1992 r., Dz. U. z 1996 r. Nr 120, poz. 564. 
a) sztuczne licytacje - kwalifikowane w zależności od stanu faktycznego jako np. oszustwo, zmowa przetargowa,

b) podbijanie cen poprzez stosowanie nielegalnych gier rynkowych, także różnie kwalifikowanych w zależności od stanu faktycznego (też tzw. żyrandolowe aukcjes5),

c) zmowa kupujących,

d) zmowa sprzedających,

e) gry spekulacyjne celem falsyfikowania (bądź ukazywania nieprawdziwych) wyników aukcyjnych i poziomu ilościowego sprzedaży, mających wpływ na poziom przyszłych cen; mogą być też nastawione na wywołanie paniki na rynku sztuki albo budowanie nieprawdziwej atmosfery idealnej kondycji rynku sztuki (np. przebijającej rynek papierów wartościowych celem przesunięcia zainteresowania inwestorów),

f) pozyskiwanie zastrzeżonych informacji czy danych osobowych uczestników rynków,

g) tworzenie baniek spekulacyjnych i piramid finansowych,

h) działalności legalizacyjna na rynku sztuki poprzez:

- uwiarygodnianie obiektów wbrew rzeczywistej ocenie (uwiarygodnianie przedmiotu transakcji) poprzez opinie, wystawy muzealne, fałszywe działania proweniencyjne/atrybucyjne,

- potwierdzanie nieprawdy w dokumentach ocen i wycen,

- fałszowanie danych i wytwarzanie fałszywych analiz rynku sztuki czy jego segmentów celem dokonania zmian na rynku (np. przejęć),

- fałszowanie ekspertyz - występuje w Polsce rzadziej niż w krajach Europy Zachodniej, gdyż nie ma w Polsce prawnego wzoru ekspertyzy, rynku eksperckiego, a odpowiedzialność tzw. eksperta z racji możliwości stosowania niejednoznacznych treściowo ekspertyz pozwala na unikanie odpowiedzialności łatwiej niż w przypadku fałszowania ekspertyzy,

i) zaniżanie wartości sprowadzanych i sprzedawanych przez pośredników dóbr kultury dla celów podatkowych,

j) unikanie opodatkowania - ukrywanie lub umyślne zaniżanie dochodów przez pośredników na rynku sztuki,

k) przeprowadzanie przez domy aukcyjne zamkniętych aukcji i niewykazywanie uzyskanych z nich dochodów.

Jako zagrożenie występujące w innych krajach, a w Polsce będące dopiero na etapie wstępnym, należy wskazać próby pozyskiwania przez zorganizowane grupy przestępcze (oraz organizacje terrorystyczne) środków finansowych na działalność poprzez uzyskiwanie pożyczek i kredytów, których zabezpieczenie stanowią

35 W. Szafrański, Od falsów z „3P” do „żyrandolowych” aukcji. Nowe zjawiska na rynku sztuki, „Cenne, Bezcenne, Utracone" 2015, nr 3-4, s. 86-91. 


\section{ARTYKUtY}

Wojciech Szafrański

zabytki/dobra kultury. Proces ten jest związany z wprowadzaniem restrykcji w sektorze bankowym, a tym samym ograniczeniem dostępu do tzw. żywej gotówki dla organizacji przestępczych ${ }^{36}$. Także przyszły rozwój w Polsce art bankingu (oferty private banking) i w ogóle działalności instytucji finansowych na rynku sztuki winien być już na etapie wstępnym monitorowany i analizowany przez właściwe służby.

\section{Mechanizmy wspierające ściganie przestępstw na rynku sztuki i ograniczenie patologii na nim występujących}

Obecne regulacje prawne pozwalają choćby w podstawowym zakresie na rozpoznanie i ściganie przestępstw na rynku sztuki. W tym jednak zakresie współpraca policji, prokuratury i Krajowej Administracji Skarbowej wydaje się niezbędna, szczególnie z uwagi na fakt wytworzonego faktycznie poprzez regulacje prawne mechanizmu tzw. nici w postaci ksiąg ewidencyjnych (z ustawy o ochronie zabytków i opiece nad zabytkami) oraz istnienie regulacji w zakresu przeciwdziałania praniu brudnych pieniędzy i wykorzystywania danych przekazywanych przez Generalnego Inspektora Informacji Finansowej (w związku z transakcjami kiedyś powyżej 15 tys. euro, obecnie - wraz z wejściem w życie ustawy z dnia 1 marca 2018 r. o przeciwdziałaniu praniu pieniędzy oraz finansowaniu terroryzmu ${ }^{37}$ - powyżej 10 tys. euro). Dodatkowo także regulacje cywilnoprawne, takie jak art. $70^{5}$ Kodeksu cywilnego ${ }^{38}$, czy z zakresu prawa autorskiego (droit de suite) mogą być wykorzystywane skutecznie do ograniczania patologii na rynku sztuki.

\section{Potencjalne problemy organów ścigania na rynku sztuki}

Wskazane w sposób ogólny i niekompletny (w zagadnieniach wstępnych) problemy organów ścigania w skutecznym ściganiu przestępstw na rynku sztuki należy usystematyzować i uszeregować w następujących grupach:

\section{Legislacyjne:}

a) zamieszanie terminologiczne co do zakresów pojęć „zabytek”, „dobro kultury" itd. i tym samym poziomu właściwej kwalifikacji prawnej, a w konsekwencji skuteczności choćby formułowania zarzutu i prowadzenia postępowania dowodowego,

b) brak regulacji prawnej rynku eksperckiego w Polsce, stanowiącego nie tylko zaplecze biegłych dla potencjalnych postępowań, ale i ułatwiają-

36 W. Pływaczewski, Patologie w obrębie współczesnego rynku dzieł sztuki - perspektywa krajowa i międzynarodowa, w: T. Gardocka, J. Sobczak (red.), Prawna ochrona zabytków, Wydawnictwo Adam Marszałek, Toruń 2010, s. 246 in.

37 Ustawa z dnia 1 marca 2018 r. o przeciwdziałaniu praniu pieniędzy oraz finansowaniu terroryzmu, tekst jedn. Dz. U. z 2019 r., poz. 1115.

38 Ustawa z dnia 23 kwietnia 1964 r. Kodeks cywilny, Dz. U. z 2018 r., poz. 1025 ze zm. 
cego w ogóle postępowania dowodowe i z natury ograniczającego patologie na rynku sztuki,

c) pozostawienie $w$ formie przepisów okołokodeksowych regulacji dotyczących przestępstw przeciw zabytkom/dobrom kultury, bez wprowadzenia osobnego działu w Kodeksie karnym,

d) brak specjalnie przeznaczonej dla rynku sztuki konstrukcji należytej staranności. W przyszłości konieczna jest zmiana legislacyjna w tym zakresie, chociażby w zakresie wprowadzenia obowiązków notyfikacyjnych nałożonych na pośredników (przedsiębiorców wyspecjalizowanych w obrocie dobrami kultury) w postaci teleinformatycznego rejestru dóbr kultury (RDK) dla transakcji, których przedmiotem są dobra kultury starsze niż 50 lat i o wartości powyżej 10 tys. euro, i jednocześnie wprowadzenie formy pisemnej pod rygorem nieważności dla przeniesienia własności takich dóbr kultury. Konieczne jest także prowadzenie bardziej miękkich działań, jak np. opisanie sposobu postępowania antykwariatów, domów aukcyjnych oraz innych podmiotów gospodarczych wyspecjalizowanych w obrocie zabytkami podczas nabywania dóbr kultury. Nie ma obecnie regulacji ustawowych, które normowałyby zasady postępowania tych podmiotów w przypadku oferowania im do sprzedania obiektu mogącego pochodzić z przestępstwa. Na marginesie należy wskazać, że nowa ustawa $z$ dnia 1 marca 2018 r. o przeciwdziałaniu praniu pieniędzy oraz finansowaniu terroryzmu wskazuje jedynie w sposób ogólny na instytucje obowiązane, czyli przedsiębiorców w rozumieniu nowej ustawy z dnia 6 marca 2018 r. Prawa przedsiębiorców ${ }^{39}$, w zakresie, w jakim przyjmują lub dokonują płatności za towary w gotówce o wartości równej lub przekraczającej równowartość 10 tys. euro, bez względu na to, czy transakcja jest przeprowadzana jako pojedyncza operacja, czy kilka operacji, które wydają się ze sobą powiązane. Tym samym brak specjalnych przepisów i wskazania domów aukcyjnych czy antykwariatów jako podmiotów wyjątkowo narażonych z racji specyfiki obrotu. Ustawodawca polski i tak będzie musiał dokonać $w$ przyszłości zmiany prawa $w$ tym zakresie ( $w$ formie implementacji), gdyż wprowadzona została nowa, tzw. 5 dyrektywa Parlamentu Europejskiego i Rady (UE) 2018/843 z dnia 30 maja 2018 r. zmieniająca dyrektywę (UE) 2015/849 w sprawie zapobiegania wykorzystywaniu systemu finansowego do prania pieniędzy lub finansowania terroryzmu oraz zmieniająca dyrektywy 2009/138/WE i 2013/36/UE ${ }^{40}$. Zgodnie z nią, wskazane

\footnotetext{
39 Ustawa z dnia 6 marca 2018 r. Prawo przedsiębiorców, Dz.U. poz. 646 ze zm.
}

40 Dyrektywa Parlamentu Europejskiego i Rady (UE) 2018/843 z dnia 30 maja 2018 r. zmieniająca dyrektywę (UE) 2015/849 w sprawie zapobiegania wykorzystywaniu systemu finansowego do prania pieniędzy lub finansowania terroryzmu oraz zmieniająca dyrektywy 2009/138/WE i 2013/36/UE, Dz. Urz. UE L 156 z 19.06.2018 r. 


\section{ARTYKUtY}

Wojciech Szafrański

są specjalnie wprost podmioty jako podmioty zobowiązane, wśród nich są w pkt „i" oraz ,j” art. 2 ust. 1 tej dyrektywy wymienione:

- osoby prowadzące handel dziełami sztuki lub występujące w charakterze pośredników w handlu dziełami sztuki, w tym gdy handel taki prowadzony jest przez galerie sztuki i domy aukcyjne, jeżeli wartość transakcji lub szeregu powiązanych transakcji wynosi co najmniej 10 tys. euro,

- osoby przechowujące dzieła sztuki, prowadzące handel dziełami sztuki lub występujące w charakterze pośredników w handlu dziełami sztuki, gdy działalność taka prowadzona jest przez wolne porty, jeżeli wartość transakcji lub szeregu powiązanych transakcji wynosi co najmniej 10 tys. euro.

Ustawodawca europejski dostrzega tym samym obszar zagrożenia w zakresie prania brudnych pieniędzy na rynku sztuki.

\section{Organizacyjne:}

a) problemy wewnątrzorganizacyjne i kadrowe w postaci braku nie tyle wyspecjalizowanego zespołu krajowego, ile zapewnienia jemu faktycznego długiego działania. Zmiany w okresie ostatniego roku związane z podpisaniem nowego porozumienia w lutym 2018 r. między Generalnym Konserwatorem Zabytków a Komendą Główną Policji (KGP) stanowią dopiero początek zmian. Podobne porozumienia, także z uwagi na zmiany organizacyjne niektórych służb, winny być podpisane między Ministerstwem Kultury i Dziedzictwa Narodowego (MKiDN) a Strażą Graniczą oraz Krajową Administracją Skarbową (KAS). Obecnie zawiadomienia o popełnieniu przestępstwa, którego przedmiotem jest dobro kultury/zabytek, i tak trafiają do właściwych miejscowo organów policji, podległych w tym obszarze prokuraturze, i przypadają na niewykwalifikowanych w tym zakresie policjantów i prokuratorów, którzy raczej mają problem z podjęciem odpowiednich działań (tu także problem agendy działania). Również z punktu widzenia wykorzystywania mechanizmu pozwalającego na zwiększenie skuteczności wykrywania i ścigania przestępstw w tym obszarze (oraz eliminowania patologii), jakim są księgi ewidencyjne (pomimo ułomności rozwiązań prawnych w tym zakresie), brak jest decyzji dotyczących choćby ustalenia, który pion policji jest odpowiedzialny za realizację obowiązku ustawowego sprawdzania prowadzenia ksiąg ewidencyjnych (i rzetelności wpisów) przez zobowiązane ustawo podmioty, co prowadzi do niewypełniania tego obowiązku, a w konsekwencji wzmacnia nieobowiązywanie tych regulacji prawnych u pośredników na rynku dzieł sztuki. Podobna sytuacja ma obecnie miejsce w przypadku KAS, choć poczynione zostały pierwsze kroki zmierzające do opracowania wewnętrznej procedury 
w tym zakresie w postaci agendy działania. Szczególnie obszar finansowej działalności rynku wymaga zdecydowanie bardziej intensywnych działań ze strony organów ścigania, a zwłaszcza KAS. Wsparcie kadrowe i logistyczne dla służb zajmujących się rynkiem sztuki jest warunkiem niezbędnych dla poprawy efektywności działań w tym obszarze ${ }^{41}$.

b) brak uproszczonych formuł wymiany wiedzy lub danych między służbami, które w zakresie swego działania mają ściganie przestępstw, których przedmiotem są dobra kultury,

c) brak skuteczności (oraz koszty) międzynarodowej pomocy prawnej w przypadku przestępstw z tzw. elementem obcym, choćby tzw. kołowego obrotu falsyfikatami ${ }^{42}$.

\section{Faktyczne:}

a) brak szkoleń poszczególnych organów w zakresie obrotu dobrami kultury oraz przestępczości i patologii na rynku sztuki. Tym samym istotne jest ciągle podnoszenie wiedzy w zakresie historii sztuki oraz funkcjonowania rynku sztuki i jego aspektów finansowo-ekonomicznych. W ostatnim czasie nastąpiła tu pewna zmiana, albowiem Krajowa Administracja Skarbowa zorganizowała dla koordynatorów wojewódzkich w zakresie zabytków szkolenie, którego jednym z elementów był obrót dziełami sztuki w 2018 r. Podobnie Krajowa Szkoła Sądownictwa i Prokuratury zorganizowała dla sędziów i prokuratorów drugie szkolenie w zakresie prawnej ochrony zabytków (w tym nielegalnego obrotu zabytkami) w 2019 r.,

b) brak współpracy organów ścigania z niezależnymi analitykami rynku sztuki, co pozwoliłoby na diagnozowanie stanu i uchwycenie przestępczości na rynku sztuki, przy jednoczesnym pojawianiu się na tym rynku coraz bardziej wyrafinowanych metod i form działania przestępców oraz skomplikowanych mechanizmów funkcjonowania jako elementu świata finansowego (pranie brudnych pieniędzy, łapownictwo, działania spekulacyjne itd.),

c) brak rzeczywistego monitoringu rynku sztuki przez jakikolwiek podmiot państwowy (działania w tym zakresie jednego z departamentów MKiDN nie są w praktyce prowadzone),

d) brak lub ograniczone środki finansowe, przy znacznych kosztach, albowiem praktycznie na każdym etapie postępowania istnieje konieczność posłużenia się biegłymi (tu też koszty badań),

\footnotetext{
41 Zob. także W. Pływaczewski, Nielegalne transakcje na rynku dzieł sztuki. Etiologia i fenomenologia zjawiska oraz możliwości przeciwdziałania, w: W. Szafrański, K. Zalasińska (red.), op. cit.

42 Zob. W. Szafrański, Nowe zjawiska w obrębie przestępczości na rynku sztuki w Polsce, w: M. Trzciński, O. Jakubowski (red.), Przestępczość przeciwko dziedzictwu kulturowemu. Diagnoza, zapobieganie, zwalczanie, Katedra Kryminalistyki Wydział Prawa, Administracji i Ekonomii Uniwersytetu Wrocławskiego, Wrocław 2016 , s. 58-60.
} 


\section{ARTYKUtY}

Wojciech Szafrański

e) brak w ogóle baz danych, których przedmiotem są zabytki/dzieła sztuki, lub brak kompatybilności tych baz. Przykładowo nie został uruchomiony do dziś Krajowy Rejestr Utraconych Dóbr Kultury. Istnieje także pewne zamieszanie, związane zapewne z okresem przejściowym, wokół przeniesienia kompetencyjnego krajowego wykazu zabytków skradzionych lub wywiezionych za granicę niezgodnie z prawem z Narodowego Instytutu Muzealnictwa i Ochrony Zbiorów do Departamentu Dziedzictwa Kulturowego za Granicą i Strat Wojennych MKiDN.

\section{Przyszłość regulacji prawnych w zakresie obrotu w aspekcie prawa ochrony dziedzictwa}

Obrót zabytkami ruchomymi (dobrami kultury) wymaga ingerencji ustawodawcy w stopniu większym, niż ma to miejsce dotychczas, ale bez kompleksowej reglamentacji rynku. Odchodzenie przez decydentów politycznych od pomysłów reglamentacyjnych rynku sztuki i minimalizowanie wpływu czynnika publicznego na rynek sztuki nie mogą jednak oznaczać braku głębokich zmian, które są uzasadnione nie tylko koniecznością ochrony dziedzictwa, ale zapewnieniem większej transparentności tego rynku jako specyficznego z racji dóbr na nim występujących, tzw. odwróconych procesów ekonomicznych, powiązań międzynarodowych oraz możliwości wykorzystywania jego specyfiki w kontekście innych rynków przynoszących gigantyczne korzyści finansowe dla świata przestępczego. W tym ostatnim punkcie należy porównać rynek sztuki do rynku broni, narkotyków czy handlu ludźmi. Z tej perspektywy widać przewagę rynku sztuki nad pozostałymi w następujących obszarach:

- handel dobrami (pochodzącymi z nielegalnych źródeł) przynosi wysokie zyski przy stosunkowo niskim ryzyku, o wiele niższym niż w przypadku pozostałych rynków,

- istnieje niska elastyczność rynku sztuki, tym samym wzrost cen nie tłumi popytu, a dodatkowo ograniczona ilość dóbr kultury i brak możliwości produkcji (z wyjątkiem falsyfikatów) wpływają na poziom cen,

- istnieje legalny rynek sztuki, w przeciwieństwie do innych wskazanych rynków, i to o zdecydowanie niższym poziomie kontroli ze strony państwa; dzieła sztuki/dobra kultury traktowane są jako dobra dodatnie, w przeciwieństwie do pozostałych „towarów” będących przedmiotami obrotu na pozostałych rynkach,

- na rynku sztuki istnieją podmioty prywatne, które mogą legalnie, bez nadzoru państwa dokonywać transakcji, łatwiej tym samym wejść $w$ rolę takich podmiotów organizacjom przestępczym; na innych rynkach takich legalnych podmiotów brak, a jeżeli są, to są one ściśle kontrolowane przez państwo, najczęściej są to podmioty z udziałem państwowym,

- na rynku tym funkcjonuje tak skomplikowany i złożony system instrumentów polityki karnej, że zamiast być to ich siłą, stało się to ich słabością 
(przykładem konwencja z Palermo z 2000 r.43); co więcej, budowa ochrony międzynarodowej ( $w$ tzw. trzecim etapie) dopiero trwa,

- istnieje większe przyzwolenie uczestników legalnego rynku na „szare” dziatania wynikające z relatywizmu rynku sztuki, wyrażającego się nie tylko w działaniach podmiotów będących efektem pogoni za inwestycyjnością, ale w konkurowaniu o ważniejsze "dobra kultury" zarówno wśród podmiotów prywatnych, jak i instytucji kultury (muzeów) czy samych państw,

- na rynku sztuki występuje całkowicie inna struktura i pojmowanie przestępczości zorganizowanej niż na pozostałych rynkach,

- dobra kultury mogą stanowić zabezpieczenie finansowe dla pozostałych wskazanych rynków; sytuacja odwrotna praktycznie nie występuje, co jest związane z samym charakterem tych przedmiotów; dobra kultury zasadniczo zawsze zyskują, a nie tracą na wartości.

Tym samym podstawowymi celami przyszłych regulacji prawnych będzie:

- zwiększenie bezpieczeństwa obrotu.

- ochrona poszczególnych składników dziedzictwa przy utrzymaniu swobody obrotu oraz celowości i opłacalności istnienia własności prywatnej ruchomych dóbr kultury.

Sposoby realizacji niniejszego celu są następujące:

a) wprowadzenie specjalnej konstrukcji należytej staranności, gdy przedmiotem obrotu są dobra kultury, a w konsekwencji współtworzenie przez ustawodawcę mechanizmów wspierających (i wypływających z tej konstrukcji), zwiększających transparentność rynku sztuki (autentyczność obiektów, wiarygodność cenową, system ekspertów i ekspertyz),

b) ustanowienie przejrzystych kryteriów ograniczeń obrotu dobrami kultury i odróżnienie od nich innego typu obowiązków (informacyjnych), które wynikać muszą wprost z łączności obrotu z systemem ochrony dziedzictwa, zapewniających różne rodzaje rekompensowania tych ograniczeń (w zależności od ich charakteru). Ograniczenia w tym zakresie mogą być zróżnicowane w odniesieniu do własności prywatnej i publicznej. W takim ujęciu wskazany cel jest możliwy do zaakceptowania przez podmioty objęte regulacją. Konieczne jest ujednolicenie i stworzenie transparentnego układu odnoszącego się do obrotu dobrami kultury, pozwalającego adresatowi na jasne odczytanie, jakie obiekty są wyłączone z obrotu, jakie są ograniczone w obrocie i według jakich kryteriów i dlaczego to ograniczenie występuje oraz wreszcie które z elementów nie są ograniczeniami obrotu, lecz jedynie obowiązkami informacyjnymi wspierającymi przede wszystkim należytą staranność w obrocie, a w konsekwencji ochronę dziedzictwa.

43 Konwencja Narodów Zjednoczonych przeciwko międzynarodowej przestępczości zorganizowanej, przyjęta przez Zgromadzenie Ogólne Narodów Zjednoczonych dnia 15 listopada 2000 r., Dz.U. z 2005 r. $\mathrm{Nr}$ 18, poz. 158. 


\section{ARTYKUEY}

Wojciech Szafrański

Aby to osiągnąć, należy uwzględnić trzy elementy - istotnie powiązane ze sobą warunki wstępne:

1. Ustalenie klasyfikacji przedmiotu ochrony, uporządkowanie definicji legalnych dziedzictwa kultury. Przy narastających regulacjach prawnych, których przedmiotem są różne składniki dziedzictwa kulturowego, a jednocześnie $z$ uwagi na faktyczne przyrastanie dziedzictwa, przy braku proporcjonalnego przyrastania środków finansowych pozwalających na zapewnienie skuteczności ochrony, a tym samym zachowania dziedzictwa, decydenci polityczni (a w konsekwencji ustawodawca) powinni myśleć w kategoriach systemu ochrony dziedzictwa. Dlatego konieczne jest dokonanie rzeczywistej zmiany świadomościowej, a nie jedynie posługiwanie się ochroną dziedzictwa jako argumentacją uzasadniającą dokonywanie dalszych zmian prawnych i ograniczeń różnego stopnia, a nie zmian ich miejsca w systemie ochrony. Nie jest to możliwe bez określenia w sposób jednoznaczny i jednorodny, co stanowi przedmiot ochrony, gdyż stan obecny (definicyjne rozproszenie) wpływa m.in. na brak spójności systemu ochrony zabytków w Polsce. Zmiana definicji przedmiotu ochrony z zabytku na dziedzictwo kultury, wprowadzenie klasyfikacji przedmiotu ochrony, a tym samym doprowadzenie do uporządkowania definicji legalnych to elementy sprzyjające włączeniu obrotu w system ochrony i zwiększeniu poziomu akceptowalności tej zmiany przez podmioty będące uczestnikami tego obrotu.

W zależności od tego, czy przedmiotem regulacji są dobra kultury (jako całość), czy zabytki (i ewentualnie inne wyodrębnione kategorie), zakres wspólnej płaszczyzny obrotu i ochrony dziedzictwa jest większy w pierwszym przypadku (rys. 1), a mniejszy w drugim (rys. 2), nawet przy uwzględnieniu innych wyodrębnionych kategorii przedmiotów ochrony, także „sztucznych”, takich jak muzealia.

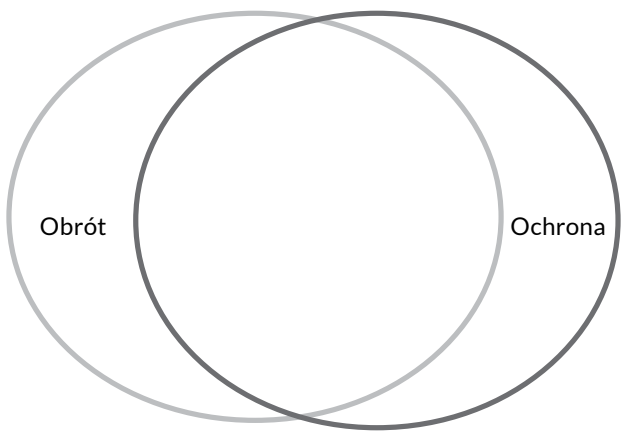

Rys. 1. Zakres wspólnej płaszczyzny, gdy przedmiotem jest dobro kultury (jako kategoria ogólna, nawet z wyodrębnionymi wewnątrz przedmiotami ochrony)

Źródło: opracowanie własne. 


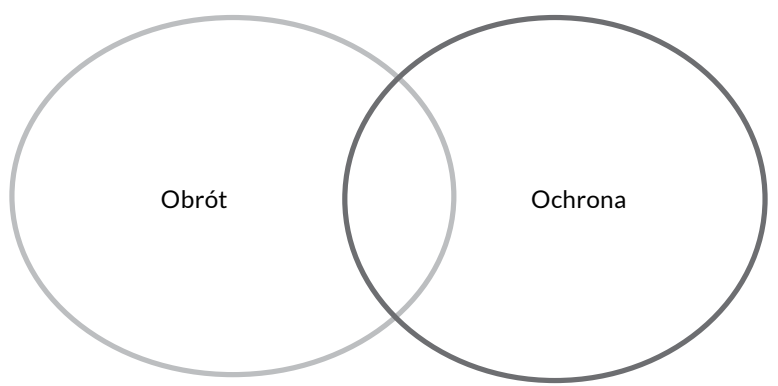

Rys. 2. Zakres wspólnej płaszczyzny, gdy przedmiotem jest zabytek (i inne wyodrębnione kategorie)

Źródło: opracowanie własne.

Sytuacja braku istnienia części wspólnej obrotu i ochrony prawie dzisiaj nie występuje, stąd też ustawodawstwa poszczególnych państw regulacje dotyczące obrotu włączają w mniejszym lub większym stopniu i w zróżnicowanej formule do systemu ochrony dziedzictwa.

Konstrukcja należytej staranności winna odnosić się w ogóle do obrotu dobrami kultury, a nie tylko zabytkami. Ma ona bowiem na celu wzmocnienie monitorowania rynku służącemu wsparciu mechanizmów zapobiegania i zwalczania nielegalnego obrotu dobrami kultury, co jest istotnym elementem wspierającym ochronę dziedzictwa. Pozostawienie w tym zakresie wyłącznie kategorii zabytku (nawet przy zmienionej definicji legalnej), choć wpisujące się w polską tradycję prawną, jest niecelowe. Już dziś istnieje w ustawodawstwie polskim silne zróżnicowanie obiektów występujących w obrocie dobrami kultury poprzez istnienie pojęć: zabytku, dobra kultury, narodowego dobra kultury, skarbu dziedzictwa itd. Podstawowe zasady należytej staranności w obrocie winny się odnosić do wszelkich dóbr kultury, część z nich wraz upływem czasu stanie się zabytkami, a z uwagi na możliwą wartość (względnie własność - jak w przypadku muzealiów) podlegać będzie pod wyodrębnione kategorie. Należy zgodzić się z twierdzeniem Moniki Dreli ${ }^{44}$, że zabytkowość rzeczy nie jest jej obiektywnie mierzalną cechą, mogącą być ocenianą przez każdego człowieka. Wydaje się, że podobnie jest z dobrami kultury, ale w tym wypadku odpada element „świadectwa minionej epoki”, równie trudno rozstrzygalny. Dobrem kultury byłby każdy przedmiot ruchomy lub nieruchomy, dawny lub współczesny, mający znaczenie dla dziedzictwa i rozwoju kulturalnego ze względu na jego wartość historyczną, naukową lub artystyczną. Pozwoli to na łatwiejsze wprowadzanie regulacji międzynarodowych i europejskich, bo dotychczasowa praktyka wtłaczania dóbr kultury w system zabytków i ich różnicowania, nie tylko semantycznego, ale kategoryzowania, powoduje coraz większą nieprzejrzystość systemu ochrony dziedzictwa w Polsce. Co istotne, ten problem szczególnie widać 


\section{ARTYKUtY}

Wojciech Szafrański

w odniesieniu do obrotu w momencie wprowadzenia regulacji restytucyjnych, ksiąg ewidencyjnych, a już niedługo regulacji importowych w związku z już rozpoczętymi pracami nad projektem rozporządzenia Parlamentu Europejskiego i Rady w sprawie przywozu dóbr kultury z 13 lipca 2017 r. Nie oznacza to, że kategoria zabytku winna zniknąć, ale nie powinna być kategorią centralną. Dlatego spojrzenie na możliwość wprowadzenia zasad należytej staranności winno mieć aspekt przede wszystkim podmiotowy i zróżnicowany w tym zakresie, a dopiero następczo przedmiotowy. 2. Włączenie obrotu dobrami kultury do systemu ochrony dziedzictwa. Obrót zabytkami/dobrami kultury z tego punktu widzenia cechował się brakiem całościowej lub choćby częściowej, ale spójnej regulacji w tym zakresie, gdyż był odbiciem ograniczeń wprowadzanych w systemie dziedzictwa, a nie samodzielnych.

Bezpieczeństwo obrotu wspiera w sposób naturalny ochronę dziedzictwa, stąd niniejszy stan prawny w Polsce wymaga zmiany poprzez stworzenie regulacji dotyczących obrotu jako należących do systemu dziedzictwa, a tym samym uznanie zasady bezpieczeństwa obrotu jako jednej z zasad prawa ochrony zabytków ruchomych (jako rozwiązanie rekomendowane). Włączenie do systemu ochrony dziedzictwa obrotu dobrami kultury poprzez regulacje dotyczące jego bezpieczeństwa wpisuje się w nasilającą się tendencję, którą dostrzec można nawet w ciągu ostatnich lat nie tylko w prawie międzynarodowym, prawie europejskim, ale i porządkach prawnych poszczególnych państw ${ }^{45}$, a która jest efektem ograniczonej skuteczności polityki ochrony dziedzictwa, opierającej się jedynie na wprowadzenia ograniczeń czy zakazów.

3. Dominacja regulacji notyfikacyjnych nad regulacjami $z$ obszaru kontroli obrotu, przy całkowitej rezygnacji z klasycznej reglamentacji obrotu. Regulacje notyfikacyjne powiązane są z wcześniejszym założeniem tworzenia przepisów składających się na bezpieczeństwo obrotu, stąd winny one mieć w głównej mierze charakter informacyjny, oparty na oświadczeniu podmiotów oraz tworzący mechanizmy monitorujące. Regulacje z obszaru kontroli obrotu winny być tworzone tylko $\mathrm{w}$ uzasadnionych przypadkach, być powiązane z konkretnymi kategoriami obiektów, przy uwzględnieniu przede wszystkim kwestii własności. Propozycja całościowej reglamentacji obrotu stanowi dziś raczej objaw bezradności projektodawców (niski poziom akceptowalności takich rozwiązań, niewspółmierność kosztów ich wprowadzenia do efektów) albo świadectwo nieznajomości funkcjonowania rynku sztuki i jako taka winna być uznawana za niecelowa ${ }^{46}$.

Rozważanie przez projektodawcę formuły kodeksu dziedzictwa tak naprawdę zmusiłoby do konieczności przeglądu nie tylko postępującego zróżnicowania przedmiotu ochrony, form i stopni oraz wpływu na nie kwestii własności i wartości, ale także ewaluacji w zakresie „ilości i wartości” dziedzictwa, a tym samym faktycznych

45 Tendencję taką widać szczególnie w prawie szwajcarskim i niemieckim, częściowo także francuskim, ale także angielskim czy amerykańskim (choć w tych ostatnich dwóch przypadkach jest ona realizowana nie tylko poprzez samą legislację, ale i koregulację czy samoregulację w zakresie due diligence na rynku sztuki).

46 Zob. szerzej: W. Szafrański, Obrót zabytkami..., s. 156-180. 
możliwości kadrowych i finansowych państwa w tym zakresie i istnienia lub nie konieczności działań ustawodawczych. Konstrukcja kodeksu dziedzictwa (ewentualnie całkowicie nowa ustawa o ochronie dóbr kultury) daje szanse dla podmiotów, choćby z racji stworzenia zasad ogólnych, wspomagających rozwiązywanie konkretnych problemów w sytuacjach granicznych, które są dziś problemem dla organów stosujących prawo (np. stanowić będą podstawę do dokonywania interpretacji).

\section{Bibliografia}

Białynicka-Birula J., Rynek dzieł sztuki w Polsce. Aspekty prawno-ekonomiczne, Ministerstwo Kultury i Dziedzictwa Narodowego [2008], http://www.kongreskultury.pl/library/ File/RaportRynekSzt/rynek_dziel_sztuki_raport_w.pelna(1).pdf [dostęp: 5.05.2019].

Drela M., Miejsce ochrony zabytków ruchomych w systemie ochrony dziedzictwa kulturowego [archiwum autora].

Dyrektywa Parlamentu Europejskiego i Rady (UE) 2018/843 z dnia 30 maja 2018 r. zmieniająca dyrektywę (UE) 2015/849 w sprawie zapobiegania wykorzystywaniu systemu finansowego do prania pieniędzy lub finansowania terroryzmu oraz zmieniająca dyrektywy 2009/138/WE i 2013/36/UE, Dz. Urz. UE L 156 z 19.06.2018 r.

Europejska Konwencja o ochronie dziedzictwa archeologicznego (poprawiona),sporządzona w La Valetta dnia 16 stycznia 1992 r., Dz. U. z 1996 r. Nr 120, poz. 564.

Gwoździewicz P., Kowalski W., Rynek sztuki [hasło], w: K. Zeidler, Leksykon prawa ochrony zabytków. 100 podstawowych pojęć, C.H. Beck, Warszawa 2010.

Jasiński W., System przeciwdziałania i zwalczania prania pieniędzy, w: E.W. Pływaczewski (red.), Proceder prania pieniędzy i jego implikacje, Wolters Kluwer Polska, Warszawa 2013.

Konwencja Narodów Zjednoczonych przeciwko międzynarodowej przestępczości zorganizowanej, przyjęta przez Zgromadzenie Ogólne Narodów Zjednoczonych dnia 15 listopada 2000 r., Dz.U. z 2005 r. Nr 18, poz. 158.

Kowalski W., Prawo ochrony zabytków w świetle aktualnych problemów zachowania dziedzictwa kulturowego Polski, w: W. Szafrański, K. Zalasińska (red.), Wokół problematyki prawnej zabytków i dzieł sztuki, t. 3, Wydawnictwo Poznańskie, Poznań 2009.

Maskin E., Riley J., Asymmetric Auctions, „Review of Economic Studies” 2000, nr 67.

Maskin E., Riley J., Optimal Auctions with Risk Averse Buyers, „Econometrica” 1984, nr 52.

Pływaczewski W., Nielegalne transakcje na rynku dzieł sztuki. Etiologia i fenomenologia zjawiska oraz możliwości przeciwdziałania, w: W. Szafrański, K. Zalasińska (red.), Wokół problematyki prawnej zabytków i dzieł sztuki, t. 3, Wydawnictwo Poznańskie, Poznań 2009.

Pływaczewski W., Patologie w obrębie współczesnego rynku dzieł sztuki - perspektywa krajowa i międzynarodowa, w: T. Gardocka, J. Sobczak (red.), Prawna ochrona zabytków, Wydawnictwo Adam Marszałek, Toruń 2010.

Pływaczewski W., Pranie pieniędzy oraz inne nielegalne transakcje finansowe z perspektywy międzynarodowego rynku dzieł sztuki, w: E.W. Pływaczewski (red.), Proceder prania pieniędzy i jego implikacje, Wolters Kluwer Polska, Warszawa 2013.

Rozporządzenie Parlamentu Europejskiego i Rady (UE) 2019/880 z dnia 17 kwietnia 2019 r. w sprawie wprowadzania i przywozu dóbr kultury, Dz. Urz. UE L 151 z 7.06.2019 r.

Rynek sztuki. Sztuka rynku - raport Deloitte z kwietnia 2013, http://rynekisztuka.pl/wp-content/uploads/2013/04/pl_artbanking_pl.pdf [dostęp: 1.02.2019]. 


\section{ARTYKUtY}

Wojciech Szafrański

Szafrański W., Handel dziełami sztuki w Polsce a gry rynkowe - zarys problematyki, w: W. Kowalski, K. Zalasińska (red.), Rynek sztuki. Aspekty prawne, Wolters Kluwer Polska, Warszawa 2011.

Szafrański W., Mity i patologie obrotu dziełami sztuki, „Santander Art and Culture Law Review" 2015, nr 1.

Szafrański W., Nowe zjawiska w obrębie przestępczości na rynku sztuki w Polsce, w: M. Trzciński, O. Jakubowski (red.), Przestępczość przeciwko dziedzictwu kulturowemu. Diagnoza, zapobieganie, zwalczanie, Katedra Kryminalistyki Wydział Prawa, Administracji i Ekonomii Uniwersytetu Wrocławskiego, Wrocław 2016.

Szafrański W., Obrót zabytkami ruchomymi, w: K. Zeidler (red.), Raport dotyczący stanu ochrony prawnej oraz kierunków zmian w zakresie prawnej ochrony zabytków ruchomych w Polsce, przygotowany w ramach Krajowego Programu Ochrony Zabytków i Opieki nad Zabytkami na lata 2014-2017 dla Narodowego Instytutu Muzealnictwa i Ochrony Zbiorów, Gdańsk 2016.

Szafrański W., Od falsów z „3P” do „żyrandolowych” aukcji. Nowe zjawiska na rynku sztuki, „Cenne, Bezcenne, Utracone" 2015, nr 3-4.

Szafrański W., Publiczne aspekty prywatnych kolekcji, w: A. Jagielska-Burduk, W. Szafrański (red.), Kultura w praktyce. Zagadnienia prawne, Wydawnictwo Poznańskiego Towarzystwa Przyjaciół Nauk, Poznań 2012.

Szafrański W., Upublicznianie kolekcji prywatnych w Polsce. Problemy prawne w praktyce, w: P. Stec (red.), Kolekcje - wystawy - muzealia. Problematyka prawna, Redakcja Wydawnictw Wydziału Teologicznego Uniwersytetu Opolskiego, Opole 2015.

Szmelter I., Kowalski W., Wystawiennictwo sztuki nowoczesnej a ochrona integralności utworów, „Muzealnictwo” 2008, nr 49.

Ustawa z dnia 15 lutego 1962 r. o ochronie dóbr kultury, Dz. U. Nr 10, poz. 48.

Ustawa z dnia 23 kwietnia 1964 r. Kodeks cywilny, Dz. U. z 2018 r., poz. 1025 ze zm.

Ustawa z dnia 14 lipca 1983 r. o narodowym zasobie archiwalnym i archiwach, tekst jedn. Dz. U. z 2018 r., poz. 217.

Ustawa z dnia 21 listopada 1996 r. o muzeach, tekst jedn. Dz. U. z 2018 r., poz. 720.

Ustawa z dnia 6 czerwca 1997 r. Kodeks karny, tekst jedn. Dz. U. z 2018 r. poz. 1600, 2077.

Ustawa z dnia 23 lipca 2003 r. o ochronie zabytków i opiece nad zabytkami, tekst jedn. Dz. U. z 2017 r., poz. 2187 ze zm.

Ustawa z dnia 20 lutego 2015 r. o rzeczach znalezionych, Dz. U. poz. 397.

Ustawa z dnia 25 maja 2017 r. o restytucji narodowych dóbr kultury, Dz. U. poz. 1086.

Ustawa z dnia 1 marca 2018 r. o przeciwdziałaniu praniu pieniędzy oraz finansowaniu terroryzmu, tekst jedn. Dz. U. z 2019 r., poz. 1115.

Ustawa z dnia 6 marca 2018 r. Prawo przedsiębiorców, Dz.U. poz. 646 ze zm.

Waltoś S., Muzealnik jako ekspert na rynku dzieł sztuki, w: R. Pasieczny (red.), Problematyka autentyczności dzieł sztuki na polskim rynku. Teoria, praktyka, prawo, Narodowy Instytut Muzealnictwa i Ochrony Zbiorów, Warszawa 2012.

Zalasińska K., Muzea uwikłane w rynek sztuki, „MOCAK Forum” 2013, nr 1.

Zalasińska K., Wpływ zmiany przepisów dotyczących wywozu zabytków za granice na rynek sztuki w Polsce, w: W. Kowalski, K. Zalasińska (red.), Rynek sztuki. Aspekty prawne, Wolters Kluwer Polska, Warszawa 2011. 